\title{
Effect of recombinant interleukin 2 on hepatitis B e antigen positive chronic hepatitis
}

\author{
M ONJI, H KONDOH, N HORIIKE, S YAMAGUCHI, Y OGAWA, I KUMON \\ AND Y OHTA \\ From the Third Department of Internal Medicine, Ehime University School of Medicine, Ehime, Japan
}

SUMMARY Eleven patients with hepatitis B (HB) virus related chronic hepatitis were treated with recombinant interleukin 2 (rIL 2). Two hundred and fifty to 1000 units were given intravenously once daily for seven to 28 days. In five patients serum glutamic pyruvic transaminase activity rose transiently. Six patients showed a decrease in HBV DNA polymerase. One patient lost HBs, e antigens (Ags) and gained anti-HBs, e antibodies, while one lost HBs Ag and another $\mathrm{HBe} \mathrm{Ag}$. $2^{\prime}-5$ 'oligoadenylate synthetase activity in mononuclear cells in the peripheral blood did not change during treatment. The number of CD4 positive (helper/inducer) cells and natural killer cell activity increased after therapy $(\mathrm{p}<0 \cdot 05, \mathrm{p}<0 \cdot 01)$. These results suggest that $\mathrm{rIL} 2$ acts as an immunomodulatory agent enhancing host immune activity and may be beneficial in patients with chronic $\mathrm{HB}$ virus infection.

It was observed by several investigators that, although there is a drop in hepatitis B virus (HBV) DNA or HBV DNA polymerase (DNA-p) in the serum of patients treated with adenine arabinoside (Ara-A) or interferon (IFN), the concentration becomes undetectable only in a small percentage of patients, and a sustained seroconversion occurs in only a minority. There are several factors affecting trials of Ara-A and IFN. The characteristics of patients treated vary substantially. Oriental people, who have a high infection rate in early life, do poorly with Ara-A and IFN, whereas northern Europeans exhibit better results.' We need new drugs in which the mechanism of action is different from that of IFN.

In $\mathrm{HB}$ virus induced liver disease, cytotoxic $\mathrm{T}$ cells are probably responsible for the destruction of liver cells.' Interleukin 2 (IL 2) causes cytotoxic T cells to increase in number and to mature. ${ }^{3} \mathrm{~T}$ cells in the peripheral blood from patients in the exacerbation stage of chronic hepatitis produce more IL 2 than in the remission stage. ${ }^{+}$There is a possibility that exogenous IL 2 may make cytotoxic T cells proliferate, and eliminate infected hepatocytes.

Address for correspondence: Dr Morikazu (Onji. Third I)epartment of Internal Medicine, Ehime University School of Medicine Shigenobu. Ehime. Japan 791-12.

Received for publication 30 April. 1987
The aim of this study was to determine whether or not IL 2 is effective in Japanese patients chronically infected with $\mathrm{HB}$ virus.

\section{Methods}

PATIENTS

Recombinant IL 2 (rIL 2) was provided by Takeda Chemical Industries Ltd (Osaka in Japan). The activity of T cell proliferation by one unit of this rIL 2 was equal to about 500 units of Gillis.

Between June 1985 and March 1986, 11 HBs antigen $(\mathrm{Ag})$ and $\mathrm{HBe} \mathrm{Ag}$ positive men (Table 1) were treated with rIL 2 . Two hundred and fifty to $1000)$ units were administered $i v$ daily for 60 minutes from seven to a maximum of 28 days. The diagnosis of chronic active hepatitis and chronic persistent hepatitis was established histologically for all patients.

Serum and plasma samples were taken before, during, and after therapy and stored at $-20^{\circ} \mathrm{C}$. HBs Ag was quantitatively assayed by haemagglutination. $\mathrm{HBe} \mathrm{Ag}$ and anti-HBe were detected by radioimmunoassay (Dinabbott). Patients were followed for a period of six months by serum titrations of the $\mathrm{HBs} \mathrm{Ag} / \mathrm{Ab}$ and $\mathrm{HBe} \mathrm{Ag} / \mathrm{Ab}$. DNA polymerase activity specific to $\mathrm{HB}$ virus was measured according to a modified method of Kaplan et al'; the 
Table $1 \quad S$-GPT activity and side effects in rIL 2 therapy

\begin{tabular}{|c|c|c|c|c|c|c|c|c|c|}
\hline \multirow[b]{2}{*}{ Case } & \multirow[b]{2}{*}{ Age } & \multirow[b]{2}{*}{ Sex } & \multirow[b]{2}{*}{ Histology } & \multicolumn{2}{|c|}{ rIL 2* therapy } & \multicolumn{3}{|c|}{$s-G P T+2$ activity } & \multirow[b]{2}{*}{ Side effect } \\
\hline & & & & $\begin{array}{l}\text { Duration } \\
\text { (days) }\end{array}$ & $\begin{array}{l}\text { Total dose } \\
\text { (U) }\end{array}$ & $\begin{array}{l}\text { Before } \\
(I U / L)\end{array}$ & $\begin{array}{l}\text { During } \\
\text { (IU/L) }\end{array}$ & $\begin{array}{l}\text { After } \\
\text { (IU/L) }\end{array}$ & \\
\hline 1 & 42 & Malc & $\mathrm{CAH} \ddagger$ & 7 & 1750 & 16 & 18 & 16 & $(-)$ \\
\hline 2 & 21 & Malc & СРH\$̆ & 7 & 3500 & 23 & 22 & 25 & Headache \\
\hline 3 & 22 & Male & $\mathrm{CAH}$ & 7 & $7(000)$ & 156 & $2(02$ & 215 & Fever \\
\hline 4 & 39 & Malc & $\mathrm{CAH}$ & 28 & 14000 & 36 & 45 & 29 & $(-)$ \\
\hline 5 & 33 & Malc & $\mathrm{CAH}$ & 28 & 140000 & 524 & 640 & 17 & $(-)$ \\
\hline 6 & 33 & Malc & $\mathrm{CAH}$ & 28 & 14000 & 175 & 127 & 72 & $(-)$ \\
\hline 7 & 32 & Male & $\mathrm{CAH}$ & 28 & 14000 & 141 & 119 & 119 & Headache \\
\hline 8 & 36 & Male & $\mathrm{CAH}$ & 28 & 14000 & 45 & 51 & 50 & Headache \\
\hline 9 & 24 & Malc & $\mathrm{CAH}$ & 28 & $14000)$ & 204 & 220 & 144 & Headache, fever \\
\hline 10) & 63 & Malc & $\mathrm{CAH}$ & 28 & 14000 & 42 & 117 & 100 & Fever \\
\hline \multirow[t]{3}{*}{11} & 29 & Malc & $\mathrm{CAH}$ & 28 & 14000 & 191 & 212 & 32 & Headache, fever \\
\hline & 34 & & & & & 141 & 161 & 74 & \\
\hline & \pm 12 & & & & & \pm 146 & \pm 175 & \pm 64 & \\
\hline
\end{tabular}

Data are shown are mean \pm one standard deviation. ${ }^{*}$ rIL 2: recombinant interleukin 2; $\$$ s-GPT is serum gultamic pyruvic transaminase. Normal range 1 to $48 \mathrm{IU}$ per litre. There was no significant difference in s-GPT activity after the administration of rIL 2; $\ddagger$ CAH: chronic active hepatitis; \$. $\mathrm{CPH}$ : chronic persistent hepatitis.

upper limit of the normal range being $200 \mathrm{cpm} /$ $500 \mu \mathrm{l}$. Serum glutamic pyruvic transaminase (s-GPT) was estimated according to routine laboratory procedure. The activity of $2^{\prime}-5^{\prime}$ oligoadenylate synthetase $(2-5$ AS) in peripheral blood mononuclear cells was measured by the column method as described by Sokawa et al, ${ }^{7}$ in order to clarify the antiviral effect of rIL 2. Columns of poly(I):poly(C)agarose $(50 \mu \mathrm{l}$ gel vol $)$ that had received $100 \mu \mathrm{g}$ mononuclear cell extract, were washed extensively with $5 \mathrm{ml}$ buffer at room temperature. They were then incubated at $33^{\circ} \mathrm{C}$ for five hours in the presence of $\left[2,8-{ }^{-} \mathrm{H}\right] \mathrm{ATP}(25 \mu \mathrm{l}, 1 \mathrm{mM} 20 \mu \mathrm{Ci} / \mathrm{ml})$. The eluates $(1 \mathrm{ml})$ from the column were collected and applied to DEAE-cellulose columns equilibrated with buffer. After the columns were washed with $10 \mathrm{ml}$ of buffer, the concentration of $\mathrm{KCl}$ was increased to $300 \mathrm{mM}$ and the eluates $(1 \mathrm{ml})$ were collected. The radioactivities were measured directly in ACS II (Amersham). 2-5 AS activity was expressed as the percentage of the conversion of the radioactivities from in-put ${ }^{3} \mathrm{H}-\mathrm{ATP}$ into ${ }^{3} \mathrm{H}-2-5 \mathrm{~A}$, and calculated by the following formula:

$$
\% \text { of conversion }=\frac{\mathrm{Net} c p m / \mathrm{ml} \text { of } 30() \mathrm{mM} \mathrm{KCl}-\text { buffer elute }}{\mathrm{Net} \mathrm{cpm} / \mathrm{ml} \text { of } 50 \mathrm{mM} \mathrm{KCl}-\text { buffer elute }} \times 100
$$

The following mouse monoclonal antibodies against human $T$ cell antigens, subsets antigens and HLA class I used were: antibody to human T helper/ inducer cell antigen [CD4] (OKT4, Ortho), antibody to human T cytotoxic/suppressor cell antigen [CD8] (OKT8, Ortho), antibody to human natural killer/ killer cell antigen (Leu 7, Becton Dickinson), antibody to human natural killer/killer cell antigen
[CD16] (Leu 11b, Becton Dickinson), and antibody to human histocompatibility antigens-A,B,C (antiHLA class I, Cappel). The lymphocytes in the peripheral blood were stained by direct immunofluorescence using fluorescein isothiocyanate labelled monoclonal antibodies. The red blood cells were removed by haemolysis using a $\mathrm{NH}_{4} \mathrm{Cl}$ solution. Twenty thousand lymphocytes were counted by flow cytometry (Spectrum III Ortho), and the percentage of lymphocytes stained with monoclonal antibodies was estimated.

Liver specimens fixed in a periodate-lysine-paraformaldehyde (PLP) fixative were stained by the immunoenzymatic technique ${ }^{*}$ using mouse monoclonal antibodies (OKT8, Leu7, anti-HLA class I). Lymphocyte subpopulations in the serial sections were expressed as the percentage of positive cells stained with each monoclonal antibody per total number of lymphocyte identified by poststaining with haematoxylin. The counting was restricted to the parenchymal area. To evaluate the intensity of HLA class I antigens on hepatocytes, the intensity of the specific staining of these antigens was assessed by a semiquantitative evaluation: - , negative; + , slight; ++ , moderate; +++ , marked. The display of HLA class I on hepatocytes may indicate the in vivo activation of IFN system.

HBs and cAgs were stained by the immunoenzymatic technique using anti-HBs antibody (Biological Medical Laboratories, Nagoya, in Japan) and anti-HBc antibody (DAKO).

Natural killer cell activity in peripheral blood was estimated by " $\mathrm{Cr}$ release assay."

Statistical analysis was done using the paired $t$ test and the Wilcoxon's matched pairs signed-ranks test. 
If there was a significant difference in both tests, the $\mathrm{p}$ value was expressed in the paired $t$ test.

\section{Results}

Table 1 represents the cases, changes in s-GPT and side effects. Three of 11 patients (case nos $3,5,10$ ) showed a transient rise in s-GPT during IL 2 therapy. There was no significant difference in s-GPT activity after rIL 2 administration. Slight headache and low grade fever were experienced by some patients during the initial stage of therapy, but there were no other side effects.

Table 2 shows the results of the serological study and the 2-5 AS activity before and after therapy. Two of 11 patients lost $\mathrm{HBs} \mathrm{Ag}$, and gained anti-HBs antibody. Two patients lost $\mathrm{HBe} \mathrm{Ag}$, one gained anti$\mathrm{HBe}$ antibody. A decrease of DNA-p activity was

Table 2 HBV markers and 2'-5' oligoadenylate synthetase activity in rIL 2 therapy

\begin{tabular}{|c|c|c|c|c|c|c|c|c|}
\hline \multirow[b]{2}{*}{ Case } & \multicolumn{2}{|c|}{$H B s A g / A b$} & \multicolumn{2}{|c|}{$H B e A g / A b$} & \multicolumn{2}{|c|}{$H B V D N A-p^{*}$} & \multicolumn{2}{|c|}{ 2-5 ASt } \\
\hline & Before & After & Before & After & Before & After & Before & After \\
\hline 1 & $+1-$ & $+1-$ & $+1-$ & $+1-$ & 314 & 217 & 0.23 & 0.35 \\
\hline 2 & $+1-$ & $+1-$ & $+1-$ & $+1-$ & 4730 & 1356 & $0 \cdot 10$ & $0 \cdot 10$ \\
\hline 3 & $+1-$ & $+1-$ & $+1-$ & $+1-$ & 639 & 437 & $0 \cdot 12$ & 0.49 \\
\hline 4 & $+1-$ & $+1-$ & $+1-$ & $+1-$ & 161 & 936 & $\mathrm{NE} \ddagger$ & 0.30 \\
\hline 5 & $+1-$ & $-1+$ & $+1-$ & $-1+$ & 798 & 193 & 0.29 & 0.06 \\
\hline 6 & $+1+$ & $-1+$ & $+1-$ & $+1-$ & 237 & 272 & $0 \cdot 15$ & 0.19 \\
\hline 7 & $+1-$ & $+1-$ & $+1-$ & $+1-$ & 468 & 273 & 0.69 & 0.37 \\
\hline 8 & $+1-$ & $+1-$ & $+1-$ & $+1-$ & 253 & 244 & $0 \cdot 18$ & 0.22 \\
\hline 9 & $+1-$ & $+1-$ & $+1-$ & $+1-$ & 182 & 198 & $0 \cdot 37$ & 0.20 \\
\hline 10 & $+1-$ & $+1-$ & $+1-$ & $+1-$ & 125 & 132 & 0.29 & 0.25 \\
\hline \multirow[t]{3}{*}{11} & $+1-$ & $+1-$ & $+1 \pm$ & $-1 \pm$ & 292 & 115 & 0.45 & 0.22 \\
\hline & & & & & 745 & 398 & 0.29 & 0.24 \\
\hline & & & & & \pm 1338 & \pm 391 & $\pm 0 \cdot 18$ & $\pm 0 \cdot 13$ \\
\hline
\end{tabular}

Data are shown as mean \pm one standard deviation. ${ }^{*} \mathrm{HBV}$ DNA-p is the abbreviation of hepatitis B virus DNA polymerase activity. Less than $200 \mathrm{cpm}$ per $500 \mu \mathrm{l}$ of HBV DNA-p is negative. There was no significant difference of HBV DNA-p after the administration of rIL- 2 . $¥ 2-5$ AS means $2^{\prime}-5^{\prime}$ oligoadenylate synthetase activity of mononuclear cells in peripheral blood. 2-5 AS is expressed as the percentage of the radioactivities from input ${ }^{3} \mathrm{H}-\mathrm{ATP}$ into ${ }^{3} \mathrm{H}-2-5 \mathrm{~A}$. There was no significant difference in 2-5 AS after rIL 2 therapy. $¥ N E$ : not examined. Case 5 lost $\mathrm{HBs}$ and $\mathrm{HBe}$ antigens, case 6 lost $\mathrm{HBs}$ antigen, and case 11 lost $\mathrm{HBc}$ antigen. These effects were probably caused by administration of IL 2.

Table $3 T$ cell subpopulations and natural killer cell activity in peripheral blood from patients with CAH type B before and after administration of rIL 2

\begin{tabular}{|c|c|c|c|c|c|c|c|c|c|c|c|c|}
\hline \multirow[b]{3}{*}{ Case } & \multicolumn{2}{|c|}{ Lymphocyte } & \multicolumn{2}{|c|}{ CD4+ cell $\ddagger$} & \multicolumn{2}{|c|}{ CD8+ cell\$ } & \multicolumn{2}{|c|}{$C D 4 / C D 8$} & \multicolumn{2}{|c|}{ CDl6+ cell } & \multicolumn{2}{|c|}{$N K$ cell\| } \\
\hline & $B^{*}$ & $A^{\dagger}$ & $B$ & $A$ & $B$ & $A$ & & $A$ & & $A$ & & $A$ \\
\hline & \multicolumn{2}{|c|}{$\left(/ \mathrm{mm}^{3}\right)$} & \multicolumn{2}{|c|}{$\left(/ \mathrm{mm}^{3}\right)$} & \multicolumn{2}{|c|}{$\left(/ \mathrm{mm}^{3}\right)$} & & & \multicolumn{2}{|c|}{$\left(/ m m^{3}\right)$} & \multicolumn{2}{|l|}{$(\%)$} \\
\hline 1 & 1860 & 1817 & 649 & 643 & 523 & 505 & 1.24 & $1 \cdot 27$ & 379 & 176 & 30 & 26 \\
\hline 2 & 1766 & 2093 & 736 & 971 & 652 & 890 & $1 \cdot 13$ & 1.09 & 71 & 151 & 6 & 29 \\
\hline 3 & 2206 & 2676 & 986 & 953 & 677 & 763 & 1.46 & 1.25 & 90 & 549 & 46 & 57 \\
\hline 4 & 2933 & 3808 & 1481 & 1858 & 754 & 838 & 1.96 & $2 \cdot 20$ & 364 & 381 & 17 & 11 \\
\hline 5 & 2523 & 3424 & 906 & 1092 & 739 & 979 & 1.23 & $1 \cdot 12$ & $4(0)$ & 811 & 16 & 28 \\
\hline 6 & 2809 & 3965 & 1053 & 1546 & 944 & 1221 & $1 \cdot 13$ & $1 \cdot 27$ & 317 & 508 & 49 & 54 \\
\hline 7 & 3009 & 2800 & 960 & 910 & 1216 & 966 & 0.79 & 0.94 & 316 & 339 & 32 & 56 \\
\hline 8 & 2679 & 3192 & 1232 & 1679 & 856 & 958 & 1.42 & 1.75 & 434 & 259 & 21 & 27 \\
\hline 9 & 1727 & 2373 & 808 & 1006 & 461 & 555 & 1.75 & $1 \cdot 81$ & 123 & 354 & 17 & 39 \\
\hline 10 & 2237 & 2366 & 709 & 1171 & 550 & 464 & 1.66 & $2 \cdot 48$ & 503 & 343 & 12 & 27 \\
\hline 11 & 2052 & 2722 & 778 & 776 & 392 & 544 & 1.54 & 1.45 & 398 & 781 & 27 & 34 \\
\hline \multirow[t]{3}{*}{ Total } & 2345 & 2839 & 936 & 1146 & 707 & 789 & 1.40 & 1.51 & 309 & 423 & 25 & 35 \\
\hline & \pm 471 & \pm 690 & \pm 249 & \pm 386 & \pm 238 & \pm 244 & $\pm(0 \cdot 33$ & $\pm 0 \cdot 50$ & \pm 148 & \pm 220 & \pm 14 & \pm 15 \\
\hline & \multicolumn{2}{|c|}{$\llcorner * 2\lrcorner$} & \multicolumn{4}{|c|}{$\lfloor * 3\lrcorner$} & & & & & \multicolumn{2}{|c|}{$\llcorner * 5\lrcorner$} \\
\hline
\end{tabular}

Data are shown as mean \pm one standard deviation. B: before administration of rIL 2; †A: after administration of rIL 2 . The number of lymphocytes after rIL 2 therapy significantly increased $(p<0 \cdot 01)$; $\ddagger C D 4$ : the number of CD4 positive cells. The number of CD4 positive cells increased after rlL 2 therapy $(\mathrm{p}<0 \cdot(05) ; \$ C D 8$ : the number of CD8 positive cells. There was no significant difference after administration of rIL 2; $\|$ NK cell: natural killer cell activity in peripheral blood. It was estimated by ${ }^{57} \mathrm{Cr}$ release assay. NK cell activity increased after rIL 2 therapy $(\mathrm{p}<0 \cdot 01)$. 
Table 4 Changes in inflammatory activity, the HBV marker, $T$ cell subpopulation and HLA class I in livers from patients administered rIL 2

\begin{tabular}{|c|c|c|c|c|c|c|c|c|c|c|c|c|c|c|c|c|c|c|c|}
\hline \multirow[b]{2}{*}{ Case } & \multicolumn{2}{|c|}{$\begin{array}{l}\text { Focal } \\
\text { necrosis }\end{array}$} & \multicolumn{2}{|c|}{$\begin{array}{l}\text { Piecemeal } \\
\text { necrosis }\end{array}$} & \multicolumn{2}{|c|}{$\begin{array}{l}\text { Kupffer cell } \\
\text { reaction }\end{array}$} & \multicolumn{2}{|c|}{$H B s A g$} & \multicolumn{2}{|c|}{$H B c A g$} & \multicolumn{2}{|c|}{$\begin{array}{l}C D 4 \$ \\
\left(/ m m^{2}\right)\end{array}$} & \multicolumn{2}{|c|}{$\begin{array}{l}C D 8 \|_{(} \\
\left(/ m m^{2}\right)\end{array}$} & \multicolumn{2}{|c|}{$\begin{array}{l}\text { Leu7 } \\
\left(/ \mathrm{mm}^{2}\right)\end{array}$} & \multicolumn{2}{|c|}{$\begin{array}{l}H L A \\
\text { class } I \pi\end{array}$} & \multirow{2}{*}{$\begin{array}{l}\text { Timing of } \\
\text { biopsy } \\
\text { (days } \ddagger \text { ) }\end{array}$} \\
\hline & $B^{*}$ & $A \dagger$ & $B$ & $A$ & $B$ & $A$ & $B$ & $A$ & $B$ & $A$ & $B$ & $A$ & $B$ & $A$ & $B$ & $A$ & $B$ & $A$ & \\
\hline 5 & +++ & + & +++ & + & $+t$ & + & +++ & $+t$ & + & - & 128 & 50 & 328 & 132 & 25 & 20 & - & ++ & 2 \\
\hline 6 & +++ & + & ++ & + & +++ & ++ & +++ & ++ & ++ & + & 30 & 22 & 94 & 70 & 20 & 10 & ++ & ++ & 1 \\
\hline 7 & ++ & + & + & - & ++ & ++ & $\mathrm{NE}^{* * *}$ & $\mathrm{NE}$ & + & + & 112 & 12 & 88 & 18 & 16 & 5 & ++ & ++ & 1 \\
\hline 9 & ++ & + & + & + & ++ & + & ++ & + & ++ & + & 42 & 16 & 108 & 52 & 7 & 5 & + & ++ & 1 \\
\hline 10 & + & + & ++ & + & ++ & + & + & - & ++ & + & 20 & 12 & 132 & 48 & 8 & 4 & ++ & ++ & 1 \\
\hline 11 & +++ & + & ++ & + & ++ & ++ & NE & NE & ++ & + & 16 & 14 & 64 & 52 & 2 & 6 & + & ++ & 1 \\
\hline \multirow[t]{2}{*}{ Total } & & & & & & & & & & & 51 & 20 & 127 & 63 & 13 & 9 & & & \\
\hline & & & & & & & & & & & \pm 49 & \pm 13 & \pm 92 & \pm 35 & \pm 8 & \pm 6 & & & \\
\hline
\end{tabular}

${ }^{*} \mathrm{~B}$ : before administration of rIL 2; $\uparrow \mathrm{A}$ : after administration of rIL 2; $\ddagger$ Days after treatment with rIL 2; $\$ C D 4$ : number of CD4 positive cells. There was no significant difference in the number of CD4 positive cells after administration of rIL 2. ||CD8: number of CD8 positive cells. The number of CD8 positive cells after rIL 2 therapy decreased compared with that before rIL 2 therapy ( $p<0$ )(15). ๆHLA class I: HLA class I on hepatocytes were stained by the immunoenzymatic technique using mouse monoclonal antibody to HLA class $I$. The intensity of the specific staining of these antigens was assessed by semiquantitative evaluation; $-:$ negative, $+:$ slight, $++:$ moderate, $+++:$ marked. ${ }^{* *} \mathrm{NE}:$ not examined.

observed in six of 11 patients. The activity of DNA-p in serum before rIL 2 administration was $745 \pm 1338$ cpm (mean \pm standard deviation, $\mathrm{n}=11$ ), and was reduced to $398 \pm 391 \mathrm{cpm}$ after therapy, this was not statistically significant. There were no significant changes in 2-5 AS activity in the patients starting therapy.

The data of $\mathrm{T}$ cell subpopulations and natural killer cell activity in peripheral blood before and after rIL 2 therapy are shown in Table 3. The number of circulating lymphocytes after treatment with rIL 2 was significantly greater than before treatment $(p<0 \cdot 01)$. CD4 positive cells also showed a significant increase after therapy $(p<0 \cdot 05)$. The number of CD8 positive cells and CD16 positive cells, however, was unchanged. Nine of 11 patients showed an increase in natural killer cell activity after rIL 2 therapy, and there was a significant increase in natural killer cell activity in patients treated with rIL $2(\mathrm{p}<0.01)$.

Histological data in case nos 5, 6, 7, 8, 9, 10 and 11 before and after therapy are shown in Table 4 . The number of intrahepatic lymphocytes decreased markedly. Focal and piecemeal necrosis decreased in all seven cases, and CD8 positive cells decreased significantly in number after therapy $(p<0 \cdot 05)$. The display of HLA class I increased in three cases (case $\operatorname{nos} 5,9,11)$.

\section{Discussion}

Recombinant IL 2 given intravenously inhibited DNA-p activity in six of 11 patients. The decrease in DNA-p activity, however, was not pronounced, and there was no significant change during therapy. The antiviral activity of rIL 2 may be weaker than that of IFN and Ara-A. rIL 2 did not increase the activity of 2-5 AS in mononuclear cells, and probably inhibited the replication of $\mathrm{HBV}$ through a different mechanism from alpha and beta IFN, which induces 2-5 AS. There is a possibility that exogenous rIL 2 induces the production of gamma IFN, which cannot induce 2-5 AS the same as alpha and beta IFN."' The associated rise in s-GPT during therapy may indicate an increased rate of lysis of infected hepatocytes, resulting from an enhanced immune response to the virus. The increase in s-GPT is probably not attributable to a direct hepatotoxic effect of IL 2, because there were no changes of liver cells in the post-treated biopsy specimens, and therapeutic doses of rIL 2 have no influence on hepatocytes in experimental animals (personal communication).

We have reported that $T$ cells from patients with chronic hepatitis produced more IL 2 during exacerbation than during remission, ${ }^{4}$ and have suggested that rIL 2 may induce a proliferation of cytotoxic $T$ cells which in turn destroy liver cells in patients with chronic hepatitis. T cells in the peripheral blood from patients with chronic hepatitis responded to exogenous IL 2, and the uptake of "H-thymidine was the same as in normal controls." We also monitored changes in lymphocyte subpopulations serially during the first 24 hours after administration of IL 2." The ratio of $\mathrm{CD} 4$ to $\mathrm{CD} 8$ positive cells significantly increased one hour after the start of rIL 2 therapy. This change was transient, however, lasting only four hours after administration of rIL 2, and serum IL 2 concentrations decreased very quickly. In the present 
study, the number of lymphocytes and CD4 positive cells, which may induce increased production of immunoglobulin, showed an increase after rIL 2 therapy. There are some reports that IL 2 increases the production of humoral antibodies by $\mathrm{B}$ cells. Ralph et al reported that high doses of IL 2 increased production of immunoglobulin. ${ }^{2}$ rIL 2 may possibly increase the production of antibodies against HB virus associated antigens. It is therefore interesting that seroconversion from $\mathrm{HBs} \mathrm{Ag}$ to anti-HBs occurred in two cases.

Recent data in Japan indicate that approximately $5-10 \%$ of patients with chronic type B hepatitis have a seroconversion from $\mathrm{HBe} \mathrm{Ag}$ to anti-HBe antibody each year. ${ }^{13}$ Two $(18 \%)$ of 11 patients in this study became negative for serum $\mathrm{HBe} \mathrm{Ag}$ for six months. This finding suggests that rIL 2 is therapeutically effective in seroconversion from $\mathrm{HBe} \mathrm{Ag}$ to anti$\mathrm{HBe}$ antibody. It is, however, important to follow $\mathrm{HBe} \mathrm{Ag}$ and anti-HBe antibody for more than one year and study the controlled trial.

There is a possibility that IL 2 increases production of HLA class I protein, because IL 2 induces the production of gamma-IFN in lymphocytes. ${ }^{14}$ In the present study, HLA class I displays on liver cells increased in three of seven cases. This increase on the infected hepatocyte membrane may enhance lysis by cytotoxic T cells sensitised to HB virus antigen.

The increase in natural killer cell activity might be advantageous in the elimination of HB virus infected hepatocytes. The effects of IL 2 upon the immune system are numerous as have already been described. These effects may create a favourable environment for the elimination of the infected liver cells by immunocytes.

The side effects were a slight and transient headache and a low grade fever. The myalgia, high fever, leucopenia and thrombocytopenia, which accompany IFN therapy, were not observed.

The length of treatment chosen was 28 days, because IFN was administered for 28 days at the beginning of clinical trial. Further studies into this problem are necessary.

These observations indicate that in $\mathrm{HBe} \mathrm{Ag}$ positive patients rIL 2 acts as an immunomodulating agent enhancing host immune activity and may be more effective than IFN and Ara-A in oriental people with chronic HB virus infection who show almost no response to antiviral therapy. A randomised, controlled study is in progress to evaluate the effectiveness of this well tolerated regime in producing longterm inhibition of $\mathrm{HB}$ virus replication and amelioration of the associated inflammatory liver disease.
The authors thank Professor S Yamamoto in Osaka City University Medical School for his support of this work. We also wish to express our thanks to Professor H C Thomas of Royal Free Hospital in London for his helpful discussion and counsel.

\section{References}

1 Thomas HC, Scully LJ. Antiviral therapy in hepatitis B infection. Br Med Bull 1985; 41: 374-80.

2 Thomas HC, Montano L. Goodall A, Rudolf de Koning, Oladapo J, Wiecliman KH. Immunological mechanism in chronic hepatitis B virus infection. Hepatology 1982; 2: $1165-215$.

3 Gillis S, Smith KA. Long term culture of tumor-specific cytotoxic T cells. Nature 1977; 268: 154-7.

4 Onji M, Kondoh H, Ohta Y. Serial observation on lymphocyte subpopulations and interleukin 2 production of $T$ cells from patients with acute viral hepatitis and chronic active hepatitis. Hepato-Gastroenterol (In press.)

5 Gillis S, Ferm MM, Ou W, Smith KA. T cell growth factors: Parameters of production and a quantitative microassay for activity. J Immunol 1978; 120: 2027-33.

6 Kaplan PM, Greenman RL, Gerin JL, Purcell RH, Robinson WS. DNA polymerase associated with human hepatitis B antigen. J Virol 1973; 12: 995-1005.

7 Shimizu N, Sokawa Y. 2'-5' Oligoadenylate synthetase activity in lymphocytes from normal mouse. $J$ Biol Chem 1979; 254: 121034-7.

8 Onji M, Kumon I, Kanaoka K, Horiike N, Ohta Y. Identification of intrahepatic lymphocyte subpopulations in patients with fulminant hepatitis by the immunoenzymatic technique using monoclonal antibodies. Hepato-Gastroenterol 1987: 34 (in press).

9 Zarling JM, McKenough M, Bach FH. A sensitive micromethod for generating and assaying allogeneically induced cytotoxic human lymphocytes. Transplantation 1976; 21 : 468-76.

10 Ikeda T, Pignatelli M, Lever AML, Thomas HC. Relationship of HLA protein display to activation of 2-5 A synthetase in $\mathrm{HBe}$ antigen or anti-HBe positive chronic HBV infection. Gut 1986; 27: 1498-1501.

11 Yamaguchi S, Onji M, Kondoh H, Miyaoka H, Ohta Y. Immunological studies on human peripheral blood during administration of rIL 2 (in press).

12 Ralph P, Jeong G, Welte K, et al. Stimulation of immunoglobulin secretion in human B lymphocytes as a direct effect of high concentrations of IL 2. J Immunol 1984; 133: 2442-5.

13 Ichida F. Clinical problems related to seroconversion of $\mathrm{HBe}$ antigen in chronic hepatitis. Acta Hepatol Japonica 1982; 23: 694-9.

14 Vilcek J, Henriksen-Destefano D, Siegel D, Klion A, Robb RL, Le J. Regulation of IFN- $\gamma$ induction in human peripheral blood cells by exogenous and endogeneously produced interleukin 2 . J Immunol 1985; 135: 1851-6. 